\author{
Asian Journal of \\ Medical and Biological Research \\ ISSN 2411-4472 (Print) 2412-5571 (Online) \\ www.ebupress.com/journal/ajmbr
}

\title{
Article \\ Detection of enteric bacteria in the popular street food chotpoti in Dhaka, Bangladesh
}

Md. Zakiul Hassan ${ }^{1,4}$, Md. Saiful Islam², Md. Salauddin ${ }^{3}$, Abu Hena Abid Zafor ${ }^{1}$, Meghan L. Scott ${ }^{4}$ and Shahinul Alam ${ }^{5}$

${ }^{1}$ Crescent Gastroliver and General Hospital, Dhaka, Bangladesh

${ }^{2}$ Dhaka Medical College Hospital, Dhaka, Bangladesh

${ }^{3}$ Department of paediatrcis, Bangabandhu Sheikh Mujib Medical University (BSMMU), Dhaka, Bangladesh

${ }^{4}$ International Centre for Diarrhoeal Disease Research, Bangladesh (icddr,b), Dhaka, Bangladesh

${ }^{5}$ Department of Hepatology, Bangabandhu Sheikh Mujib Medical University (BSMMU), Dhaka, Bangladesh

*Corresponding author: Dr. Md. Zakiul Hassan, Programme for Emerging Infections, Infectious Diseases Division, International Centre for Diarrhoeal Disease Research (icddr, b), Bangladesh. Phone: +88 $028860523-$ 32 (Extension: 2547); Mobile: +8801753866573; E-mail: zhassan@icddrb.org

Received: 17 November 2016/Accepted: 24 November 2016/ Published: 29 December 2016

\begin{abstract}
Contaminated street food has been linked to food-borne illness and food-borne outbreak. Chotpoti is a popular street food in Bangladesh. This study was conducted to identify enteric bacteria in chotpoti sold in different parts of the capital city Dhaka. From July to October, 2012 we purposively selected 18 sites where chotpoti was sold in Dhaka city. From each site we randomly selected six chotpoti stalls for sample collection. At each stall we aseptically collected approximately $100 \mathrm{gm}$ of a combined sample of chotpoti, chili sauce and water used for cleaning utensils. The combined sample was homogenized and was serially diluted in a sterile test tube with normal saline to obtain a dilution up to $10^{-5}$. From each test tube $0.1 \mathrm{ml}$ of dilution was plated on to MacConkey and Blood agar plates under aerobic conditions at $37^{\circ} \mathrm{C}$ for 24 to 48 hours. Bacterial growth was identified by the colonial morphology, Gram stain, and biochemical tests. Of the 108 samples we analyzed, 84 (78\%) were contaminated with bacterial pathogens. Among isolated organisms Acinetobacter (66\%) was the most dominant followed by Klebsiella spp. (54\%), E. coli (3\%) and Proteus spp. (0.9\%). Two different organisms were present in 47 (44\%) samples. In half of the study sites, every sample was contaminated; in only one site bacterial contamination was absent in all samples. Contaminated street food like chotpoti may cause food borne illness and pose risk of food borne epidemics. Further studies are required for quantitative assessment of pathogens to detect potential sources of contamination and to develop interventions that can effectively reduce street food contamination.
\end{abstract}

Keywords: street food; chotpoti; microbiological contamination; food safety; Bangladesh

\footnotetext{
1. Introduction

Food-borne disease (FBD) has been recognized as a growing public health problem worldwide (Bondi et al., 2014). In the United states, FBD causes approximately 76 million illnesses, 325000 hospitalizations and 5000 deaths annually (Mead et al., 1999). In Bangladesh, about 30 million people suffer from food borne illnesses each year (FAO, 2012). FBD includes a wide range of illness caused by bacterial, viral, parasitic or chemical contamination of food (Cliver et al., 2011). Diarrheal diseases are the commonest form of FBD (Keusch et al., 2006). Approximately 2.2 million deaths caused by diarrheal diseases are recorded annually worldwide and most of these cases are attributed to contaminated food and water (WHO, 2002; Teplitski et al., 2009).

Contamination of street food by chemical and microbiological pathogen is believed to be a significant contributor to FBD (FAO, 1999). People consuming street vended food have been reported to suffer from food-
} 
borne diseases like diarrhea, cholera, typhoid fever and food poisoning (Rane, 2011). Street food has often been associated with travelers' diarrhea (Ericsson, 2003). A study on risk factors for acute and persistent diarrhea in urban Ghana revealed that about $60 \%$ of mothers supplemented their children's diet with street food and that there were higher levels of contamination in the street food given to these children than in food cooked at home. The study also showed that children who were feed street food had an increased risk of both acute and persistent diarrhea (Mensah et al., 2002). Food handlers can also become carriers of pathogenic food microorganisms such as Salmonella spp. (Zaid et al., 2011). Vollard et al. (2004) identified street food as an independent risk factor for typhoid and paratyphoid fever caused by Salmonella typhi and Salmonella paratyphi respectively and showed that one in every twenty-five food vendors excreted Salmonella spp. in their feces.

Microbiological studies carried out on street-food vending in several developing countries have reported high bacterial counts in food (Das et al.; Dawson and Canet, 1991; Ghosh et al., 2007a; Mahale et al., 2008b; Feglo and Sakyi, 2012). A study on street vended Chilli sauces in Mexico City showed $40 \%$ of samples with fecal contamination and 5\% harbored sufficient enterotoxigenic Escherichia coli to cause disease (Estrada-Garcia $e t$ al., 2002). A study on various types of ready-to-eat-food samples in Alice, South Africa showed bacterial growth in all the food types tested and found $22 \%$ of samples contaminated with Listeria spp. $18 \%$ with Enterobacter spp. $12 \%$ with Aeromonas hydrophila, $8 \%$ with Klebsiella oxytoca, $6.3 \%$ with Proteus mirabilis, $3.2 \%$ with Staphylococcus aureus and $2.4 \%$ with Pseudomonas luteola (Nyenje et al., 2012). Microbiological analysis of street vended fruit Juices from Mumbai city, India showed a total viable counts of $\log 6.5 \mathrm{cfu} / 100 \mathrm{ml}$ in all 30 samples with significant load of coliforms, faecal coliforms, Vibrio and Staphylococcal counts (Mahale et al., 2008a). Many of the pathogens isolated from street vended food has been reported to be resistant to commonly used antibiotic (Bello et al., 2013). Street vended food has also been implicated in several outbreaks of food borne diseases. In 1981, a cholera epidemic in Pune city, India was attributed to contaminated sugar cane juice with added ice, the ice was found to be contaminated with Vibrio Cholerae (Bhat and Waghray, 2000). In Senegal, more than 200 food poisoning cases were reported following consumption of dairy products (Dawson and Canet, 1991). In Cuba, 14 people died and 70 were hospitalized after eating fried foods sold by private vendor (Kubheka et al., 2001a). Street foods were responsible for 691 food poisoning outbreaks and 49 deaths from 1983 to 1992 in Shandong province, China (Xingling, 2003).

Like many developing countries, with rapid urbanization the street food industry is growing in Bangladesh .The street food vendors operate their business in bus terminals, industrial areas, market places, streets and railway stations (Suneetha et al., 2011). During holidays, festivals, and weekends the floating population highly increase and more people consume street food. The street food industry feeds thousands of people daily with a range of food items. It also plays an important role in providing employment opportunities for millions of men and women with limited education or skills, especially as the initial investment is low (Kubheka et al., 2001b; Ghosh et al., 2007b). Street foods have unique flavor, are easily accessible and cheap (Tambekar et al., 2008; Jouve et al., 2010). These foods are also the source of nutrition for the poor urban people. While street foods are an important source of ready-to-eat nutritious, low-cost meals for the urban poor, the health risk posed by such foods may outweigh their benefits (WHO, 2013). Street foods displays on open yards and easily be contaminated by dust, smoke, insects, hands of intending buyers and rains. The places has limited access to basic sanitary facility such as running water, garbage disposal and clean toilets (Feglo and Sakyi, 2012). A study of the socio-economic conditions and determination of the hygienic and sanitary practices of street food vendors in Dhaka city corporation area by FAO in 2010 demonstrated that $25 \%$ street food vendors have no formal education. They reportedly work for 13 to 18 hours a day without having toilet facilities. Most of the vending shops $(68 \%)$ were located on the footpath irrespective of areas surveyed and $30 \%$ vending carts were placed near municipal drains and $18 \%$ near sewage. A microbiological study on different foods items, drinking water and hand swab samples revealed high numbers of aerobic bacteria and coliform count. The study also suggested the need to conduct a detailed microbial analysis and profile their drug resistance characteristics to assess the potential public health hazards (FAO, 2012).

Chotpoti, a mixture of potatoes, chickpeas, onions, and chilies topped with grated egg, is one of the most popular street foods in Bangladesh. People of all ages and socioeconomic levels frequently consume chotpoti. Chotpoti stalls are available in most public places such as bus stop, market places, parks, school, colleges and university premises. On an average 50-100 consumers take chotpoti from each stall each day. Because it is widely consumed and the popularity is ever increasing and previous studies did not exclusively concentrated on this food item, we designed this study to evaluate the detailed microbial status including food borne pathogen and spoilage bacterial content of chotpoti sold in different parts of Dhaka, the capital city, Bangladesh. 
2. Materials and Methods

\subsection{Study site and study population}

Between July 2012 and October, 2012, we purposively selected 18 study sites including marketplaces, bus stops, roadside stalls and amusement parks located within Dhaka metropolitan area, an urban setting with an area of 360 square kilometers and a population of about 15 million (Figure 1).These sites are popular places for chotpoti vending and consumption, where many people eat chotpoti as an evening snack. Our study participants were chotpoti vendors who sell chotpoti within Dhaka metropolitan area.

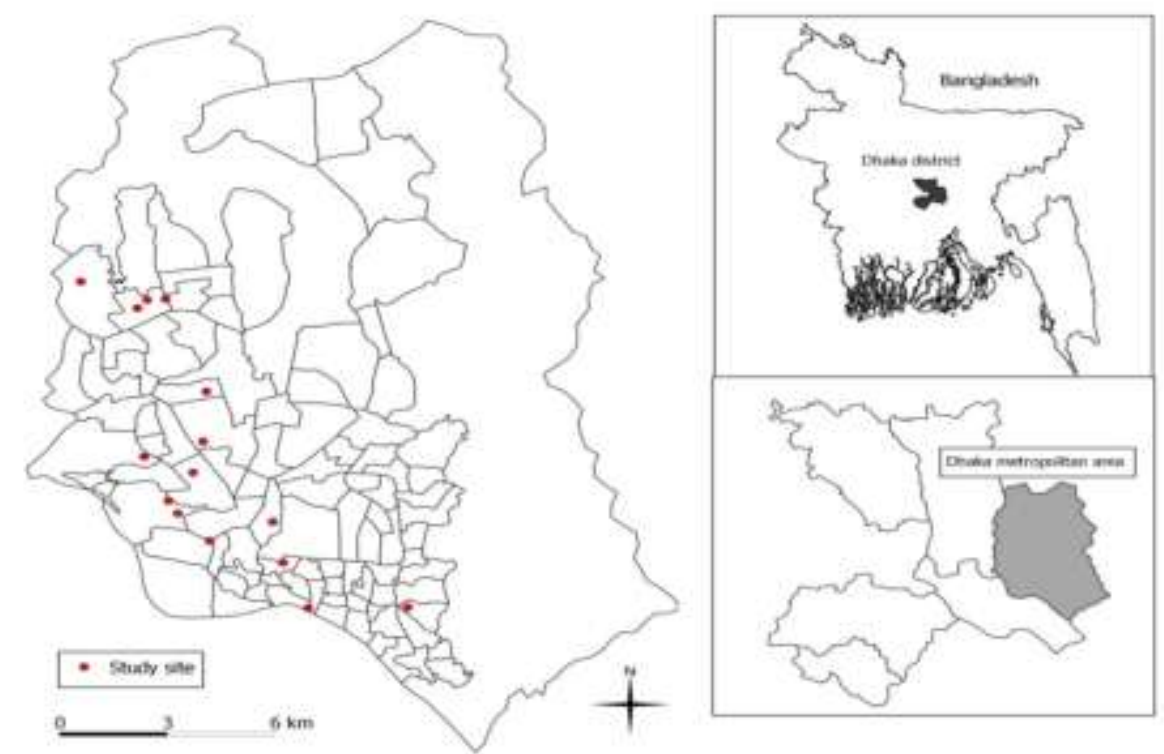

Figure 1. Location of study sites in Dhaka Metropolitan Area.

\subsection{Selection of chotpoti stalls}

Data was not available on the total number of chotpoti vending sites and exact number of chotpoti vendors in Dhaka metropolitan area, so considering our time and resources we purposively selected 18 study sites for sample collection. At each study site there were usually 15 to 20 chotpoti stalls. From each study site we selected six chotpoti stalls. First we numbered every stall. Then we randomly selected six stalls using random number table and collected data and samples from 108 vendors.

\subsection{Sample collection}

From each stall, trained field assistants collected chotpoti, chili sauce and water used for cleaning utensils. All three types of samples were combined and collected in one sterile container for each stall. Approximately 100 gm of combined sample was collected from each stall. The container was placed in a cool box maintaining a temperature of between $4^{\circ}-6^{\circ} \mathrm{C}$. The samples were labeled, packaged and sent to the Bangabandhu Sheikh Mujib Medical University (BSMMU) Microbiology laboratory in Dhaka for analysis within four hours of collection.

\subsection{Isolation and identification of microorganisms}

Laboratory personnel isolated and identified microbes using serial dilution and spread plate technique. One gram of the combined sample was homogenized using a sterile mortar and pestle. One milliliter of the resultant homogenate was added to $9 \mathrm{ml}$ of sterile normal saline in a test tube and diluted serially to obtain $10^{-1}, 10^{-2}, 10^{-3}$, $10^{-4}$ up to $10^{-5}$ dilutions. From each test tube $0.1 \mathrm{ml}$ of the dilution was aseptically pipetted out and plated onto MacConkey agar and blood agar. All the bacterial plates were incubated in an inverted position under aerobic conditions at $37^{\circ} \mathrm{C}$ for 24 to 48 hours. The inoculated plates were then observed for bacterial growth. Confirmatory identification of the bacterial pathogen was done by gram staining and biochemical tests (Kannan, 2002). Identification of bacterial pathogens was carried out according to Bergey's Manual (Sneath et al., 1986).

\subsection{Data analysis}

We calculated the percentage of contaminated samples. Contamination was defined as presence of one or more pathogens in a sample. We also calculated the percentage of different types of pathogens present in combined 
chotpoti samples. Percentage of contaminated samples from each study site was also calculated to identify the sites with the highest level of contamination.

\subsection{Ethical considerations}

The chotpoti vendors provided informed written consent both for the interview and to provide samples for laboratory testing.

\section{Results}

A total of 108 samples were collected and analyzed and $84(78 \%)$ were contaminated. We isolated Acinetobacter in $71(66 \%)$ samples, Klebsiella spp. in 58 (54\%), E. coli in 3 (2.8\%), and Proteus spp. in 1 $(0.9 \%)$ samples. Two different pathogens were present in 47 (44\%) samples (Table 1).

One hundred percent of the samples were contaminated at half of the study sites. In one site bacterial contamination was absent in all samples (Table 2).

Table 1. Types of isolated bacteria in combined chotpoti samples $(\mathrm{N}=108)$ in Dhaka, Bangladesh during July-October, 2012.

\begin{tabular}{ll}
\hline Types of bacteria & Number $(\%)$ of positive samples \\
\hline Acinetobacter & $71(66)$ \\
Klebsiella spp. & $58(54)$ \\
E. coli & $3(2.8)$ \\
Proteus spp. & $1(0.9)$ \\
More than one type of bacteria & $47(44)$ \\
\hline
\end{tabular}

Table 2. Percentage of contaminated chotpoti samples ( $\mathrm{N}=6)$ by vending site, Dhaka, Bangladesh.

\begin{tabular}{ll}
\hline Vending place & Number $(\%)$ of contaminated samples \\
\hline Shahbag & $6(100)$ \\
Dhaka Zoo, Mirpur & $6(100)$ \\
Rayer Bazar & $6(100)$ \\
Babubazar, Mitford & $6(100)$ \\
Donia College & $6(100)$ \\
Mohammadpur Bus stop & $6(100)$ \\
Shishu Park & $6(100)$ \\
Zigatola, Dhanmondi & $6(100)$ \\
Mirpur-10 Bus Stop & $6(100)$ \\
Mirpur Stadium & $5(83)$ \\
Suhrawardi Uddan & $5(83)$ \\
Dhanmondi-15 & $5(83)$ \\
Parliament area & $4(67)$ \\
Jatrabari bus stop & $4(67)$ \\
Jurain Rail gate & $4(67)$ \\
IDB Vhaban & $2(33)$ \\
New Market & $2(33)$ \\
Benaroshi Polli, Mirpur & $0(0)$ \\
\hline
\end{tabular}

\section{Discussion}

We detected at least one of four types of enteric bacteria in more than three-fourths of the chotpoti samples. The predominant bacterium was Acinetobacter. All study sites but one sold contaminated chotpoti. These results provide evidence for the potential risk of chotpoti consumption and useful directions for further research to develop intervention strategy.

Acinetobacter, Klebsiella, E. coli, and Proteus are transmitted via contaminated food and water (Leclerc et al., 2002). In our setting, contamination might be primarily due to the water used for food preparation, since chotpoti vendors use municipal tap water which is often contaminated (Faruque et al., 2010; Nahar et al., 2011). Contamination might also occur due to poor food handling practices of the vendors as most vendors lack awareness and knowledge of food safety and have not been formally trained in food safety (Fang et al., 2003; Duff SP, 2003; Barro et al., 2006b; Chukuezi, 2010; Al Mamun et al., 2013). Bacterial transmission via flies might also occur (De Jesús et al., 2004; Barro et al., 2006a). 
The isolated pathogens can cause mild to severe disease including food poisoning (Leclerc et al., 2002). Acinetobacter was the predominant pathogen in this study whereas E.coli was found in a small proportion of samples. In many other studies, E. coli was detected frequently in street food samples (Bhaskar et al., 2004; Estrada-Garcia et al., 2004; Hanashiro et al., 2005; Lewis et al., 2006). Acinetobacter is transmitted via contaminated hands and environmental surfaces (CDC, 2014a) indicating poor hand hygiene of the vendors. This aerobic gram-negative bacteria is widely distributed in the environment (soil, water, food sources, environmental surfaces and people's skin) (CDC, 2014a). Acinetobacter is harmless in most healthy people but some species may cause life-threatening hospital acquired infection including pneumonia, blood stream infection and urinary tract infection (Fournier et al., 2006; Visca et al., 2011). We should be concerned about the presence of this increasingly antibiotic resistant emerging pathogen in food samples because it might cause widespread outbreaks both in hospital setting and community setting (Barbolla et al., 2003; Perez et al., 2007). Presence of E.coli implies fecal contamination of water and ingredients used for chotpoti preparation or hand contamination of the vendors. The infectious dose of E. coli is large $\left(10^{6}-10^{8}\right.$ of organisms) and pathogenicity depends on strains (CDC, 2014b). Some strains cause diarrhea, others causes urinary tract infection, respiratory illness and other illnesses (Todar, 2016). Further studies could characterize the pathogen at species level and quantify risks associated with different species. Proteus is also transmitted through contaminated food and water and is commonly responsible for urinary and septic infection (Coker et al., 2000; Ronald, 2002).The presence of respiratory pathogens such as Klebsiella might be attributed to the bacterial aerosols generated from sneezing and coughing in public places (Fiegel et al., 2006). Klebsiella can lead to a wide range of diseases including pneumonia, urinary tract infections, septicemia, and soft tissue infections (Podschun and Ullmann, 1998).

We detected bacterial presence at genus level and did not quantify or use any bacterial parameters to detect microbial quality of food samples. Therefore it was not possible to assess the actual risks associated with chotpoti consumption, as the presence of a bacterial pathogen does not always carry a risk if the total count is low. However, all the identified bacteria are pathogenic and can cause a range of food borne illness, which is suggestive of a potential risk of chotpoti consumption. We collected combined chotpoti samples (chotpoti, chili sauces and water used for cleaning utensil) in one container so it was not possible to identify which of these three components was contaminated. Further study could specifically test each component to obtain more precise information about the source of contamination to design specific interventions. Without a complete list of all available chotpoti vending sites in the Dhaka metropolitan area, we selected some of the popular locations purposively as study sites. Therefore the results may not be generalizable to all chotpoti vendors within the Dhaka metropolitan area or other urban settings in Bangladesh or other low-income countries. However, these results might be generalizable to some of the other food items sold by street vendors in the study sites.

\section{Conclusions}

Consumption of contaminated street vended food like chotpoti may pose risk of foodborne illness and even food borne epidemics. Frequent occurrence of nosocomial pathogens like Acinetobacter highlights the need to increase awareness among vendors and consumers about food safety. Education and training of street food vendors on personal and food hygiene could improve their food handling practices and might reduce food contamination. Further studies are required for quantitative enumeration of pathogens and to identify potential sources of contamination to develop effective intervention strategies that will improve the safety of street food.

\section{Acknowledgements}

This study was funded by Crescent Gastro Liver \& General Hospital Ltd. Laboratory support was provided by the microbiology laboratory at Bangabandhu Sheikh Mujib Medical University (BSMMU), Dhaka, Bangladesh.

\section{Conflict of interest}

None to declare.

\section{References}

Al Mamun M, SMM Rahman and TC Turin, 2013. Knowledge and Awareness of Children's Food Safety Among School-Based Street Food Vendors in Dhaka, Bangladesh. Foodborne Pathog. Dis., 10:323-330.

Barbolla RE, D Centron, A Di Martino, S Maimone, C Salgueira, A Famiglietti, C Vay and M Catalano, 2003. Identification of an epidemic carbapenem-resistant Acinetobacter baumannii strain at hospitals in Buenos Aires City. Diagn. Microbiol. Infect. Dis., 45:261-264. 
Barro N, S Aly, OCA Tidiane and TA Sababenedjo, 2006a. Carriage of bacteria by proboscises, legs, and feces of two species of flies in street food vending sites in Ouagadougou, Burkina Faso. J. Food Prot., 69:20072010.

Barro N, A Bello, A Savadogo, C Ouattara, A Ilboudo and A Traore, 2006b. Hygienic status assessment of dish washing waters, utensils, hands and pieces of money from street food processing sites in Ouagadougou (Burkina Faso). African Journal of Biotechnology, 5: 30-35

Bello OO, TK Bello and SA Bankole. 2013.Occurrence of antibiotic-resistant Staphylococcus aureus in some street-vended foods in Ogun State, Nigeria. Journal of Advances in Biology, 1:21-28.

Bhaskar J, M Usman, S Smitha and GK Bhat, 2004. Bacteriological profile of street foods in Mangalore. Indian J. Med. Microbiol., 22:197.

Bhat RV and K Waghray, 2000. Profile of Street Foods Sold in Asian Countries. Street foods., 86:53-99.

Bondi M, P Messi, PM Halami, C Papadopoulou and S de Niederhausern, 2014. Emerging Microbial Concerns in Food Safety and New Control Measures. BioMed Research International, 2014:312-312.

CDC, 2014a. E. Coli (Esherichia Coli) in USA. Available: http://www.cdc.gov/ecoli/.

CDC, 2014b. Acinetobacter in Healthcare Settings in USA. Available: http://www.cdc.gov/hai/organisms /acinetobacter.html

Chukuezi CO, 2010. Food safety and hyienic practices of street food vendors in Owerri, Nigeria. Studies in Sociology of Science, 1:50-57.

Cliver DO, M Potter and HP Riemann, 2011. Foodborne infections and intoxications: Academic Press.

Coker C, CA Poore, X Li and HL Mobley, 2000. Pathogenesis of Proteus mirabilis urinary tract infection. Microb. Infect., 2:1497-1505.

Das A, GS Nagananda, S Bhattacharya and S Bhardwaj, 2010. Microbiological Quality of Street-Vended Indian Chaats Sold in Bangalore. J. Biol. Sci., 10:255-260.

Dawson R and C Canet,1991. International activities in street foods. Food Control, 2:135-139.

De Jesús AJ, AR Olsen, JR Bryce and RC Whiting, 2004. Quantitative contamination and transfer of Escherichia coli from foods by houseflies. Int. J. Food Microbiol., 93:259-262.

Duff SP SE, MS Malfios, EC Todd, LR Krilov, AM Geddes and SJ Ackerman, 2003. Cost effectiveness of targeted distribution program in household kitchens to prevent foodborne illness in the United States, Canada and the United Kingdom. J. Food Protect., 86: 2103-2115.

Ericsson CD, 2003.Travellers' diarrhoea. Int. J. Antimicrob. Agents, 21:116-124.

Estrada-Garcia T, J Cerna, M Thompson and C Lopez-Saucedo, 2002. Faecal contamination and enterotoxigenic Escherichia coli in street-vended chili sauces in Mexico and its public health relevance. Epidemiol. Infect., 129:223-226.

Estrada-Garcia T, C Lopez-Saucedo, B Zamarripa-Ayala, M Thompson, L Gutierrez-Cogco, A ManceraMartinez and A Escobar-Gutierrez, 2004. street-vended food of open markets (tianguis) and general hygienic and trading practices in Mexico City., 132:1181-1184.

Fang TJ, Q K Wei, C W Liao, M J Hung and T H Wang, 2003. Microbiological quality of 18 C ready-to-eat food products sold in Taiwan. Int. J. Food Microbiol., 80:241-250.

FAO, 2012. National food policy capacity strengthening programme. Final report PR. Available: http://www.nfpcsp.org/agridrupal/

Faruque Q, QF Haque, HU Shekhar and S Begum, 2010. Institutionalization of Healthy Street Food System in Bangladesh: A Pilot Study with Three Wards of Dhaka City Corporation as a Model. National Food Policy Capacity Strengthening Programme (NFPCSP).

Feglo P and K Sakyi, 2012. Bacterial contamination of street vending food in Kumasi, Ghana. Journal of Medical and Biomedical Sciences, 1:1-8.

Fiegel J, R Clarke and DA Edwards, 2006. Airborne infectious disease and the suppression of pulmonary bioaerosols. Drug Discovery Today, 11:51-57.

Fournier PE, H Richet and RA Weinstein, 2006.The epidemiology and control of Acinetobacter baumannii in health care facilities. Clinical Infectious Diseases, 42:692-699.

Ghosh M, S Wahi, M Kumar and DA Ganguli, 2007a. Prevalence of enterotoxigenic Staphylococcus aureus and Shigella spp. in some raw street vended Indian foods. Int. J. Environ .Health Res., 17:151-156.

Ghosh M, S Wahi, M Kumar and A Ganguli, 2007b. Prevalence of enterotoxigenic Staphylococcus aureus and Shigella spp. in some raw street vended Indian foods. Int. J. Environ. Health Res., 17:151-156.

Hanashiro A, M Morita, GR Matté, MH Matté and EA Torres,2005. Microbiological quality of selected street foods from a restricted area of Sao Paulo city, Brazil. Food Control, 16:439-444. 
Jouve J L, J Aagaard-Hansen and A Aidara-Kane,2010. Food safety: equity and social determinants. Equity, Social Determinants and Public Health Programmes, 8:95.

Kannan N, 2002. Laboratory manual in general microbiology: Panima publishing corporation.

Keusch GT, O Fontaine, A Bhargava, C Boschi-Pinto, ZA Bhutta, E Gotuzzo, J Rivera, J Chow, SA ShahidSalles and R Laxminarayan, 2006. Diarrheal diseases. Disease Control Priorities in Developing Countries, 2:371-388.

Kubheka L, F Mosupye and A Von Holy, 2001a. Microbiological survey of street-vended salad and gravy in Johannesburg city, South Africa. Food control, 12:127-131.

Kubheka LC, FM Mosupye and A Von Holy, 2001b. Microbiological survey of street-vended salad and gravy in Johannesburg city, South Africa. Food control, 12:127-131.

Leclerc H, L Schwartzbrod and E Dei-Cas, 2002. Microbial agents associated with waterborne diseases. Critical Reviews in Microbiology, 28:371-409.

Lewis JE, P Thompson, B Rao, C Kalavati and B Rajanna, 2006. Human bacteria in street vended fruit juices: A case study of Visakhapatnam City, India. Internet Journal of Food Safety, 8:35-38.

Mahale DP, RG Khade and VK Vaidya, 2008. Microbiological analysis of street vended fruit juices from Mumbai city, India. Internet Journal of Food Safety, 10:31-34.

Mead PS, L Slutsker, V Dietz, LF McCaig, JS Bresee, C Shapiro, PM Griffin and RV Tauxe,1999. Foodrelated illness and death in the United States. Emerg. Infect. Dis., 5:607.

Mensah P, D Yeboah-Manu, K Owusu-Darko and A Ablordey,2002. Street foods in Accra, Ghana: how safe are they? Bull World Health Organ, 80:546-554.

Nahar A, M Ahmed and A Chakraborty, 2011. A quality analysis of Dhaka WASA drinking water: detection and biochemical characterization of the isolates. J. Environ. Sci. Nat. Resour., 4:41-49.

Nyenje ME, CE Odjadjare, NF Tanih, E Green and RN Ndip, 2012. Foodborne pathogens recovered from ready-to-eat foods from roadside cafeterias and retail outlets in Alice, Eastern Cape Province, South Africa: public health implications. Int. J. Environ. Res. Public Health, 9:2608-2619.

Perez F, AM Hujer, KM Hujer, BK Decker, PN Rather and RA Bonomo, 2007. Global challenge of multidrugresistant Acinetobacter baumannii. Antimicrob. Agents Chemother., 51:3471-3484.

Podschun R and U Ullmann, 1998. Klebsiella spp. as nosocomial pathogens: epidemiology, taxonomy, typing methods, and pathogenicity factors. Clinical Microbiology Reviews, 11:589-603.

Rane S , 2011. Street vended food in developing world: hazard analyses. Indian J. Microbiol., 51:100-106.

Ronald A , 2002. The etiology of urinary tract infection: traditional and emerging pathogens. The American Journal of Medicine, 113:14-19.

Sneath PH, NS Mair, ME Sharpe and JG Holt, 1986. Bergey's manual of systematic bacteriology. Volume 2: Williams \& Wilkins.

Suneetha C, K Manjula and B Depur, 2011. Quality assessment of street foods in Tirumala. Asian J. Exp. Biol. Sci. , 2:207-211.

Tambekar D, V Jaiswal, D Dhanorkar, P Gulhane and M Dudhane, 2008. Identification of microbiological hazards and safety of ready-to-eat food vendee in streets of Amravati City, India. J. Appl. Biosci., 7:195-201.

Teplitski M, AC Wright and G Lorca,2009. Biological approaches for controlling shellfish-associated pathogens. Curr. Opin. Biotechnol., 20:185-190.

Todar K, 2016, pathogenic E. Coli. USA: University of Wisconsin-Madison Department of Bacteriology, USA.

Visca P, H Seifert and KJ Towner, 2011. Acinetobacter infection-an emerging threat to human health. IUBMB life, 63:1048-1054.

Vollaard AM, S Ali, HA van Asten, S Widjaja, LG Visser, C Surjadi and JT van Dissel, 2004. Risk factors for typhoid and paratyphoid fever in Jakarta, Indonesia. JAMA, 291:2607-2615.

WHO, 1999. Food safety: An essential public health issue for the new millennium: Food Safety Programme, Department of Protection of the Human Environment, Cluster of Sustainable Development and Healthy Environments. Available: http://www.who.int/iris/handle/10665/65971

WHO, 2013. International Food Safety Authorities Network (INFOSAN). Available: http://www who int/foodsafety/fs_management/infosan/en/Accessed 8

WHO, 2002. WHO global strategy for food safety: safer food for better health. Available: http://www.who.int/ iris/handle/10665/42559

Xingling S , 2003. Analysis of food poisoning in Shandong province, China from 1984 to 2000 . Chinese Journal of Food Hygiene, 2:008.

Zaid K, H Jamal and CKL Razak, 2011. The prevalence of microbiological contamination in ready-to-eat food and factors affecting it in Melaka. J. Commun. Health, 17:64-73. 